\title{
Folding Mechanism in the Asmari Anticline, Zagros, Iran
}

\author{
Azar Khodabakhshnezhad1,3, Mehran Arian2 ${ }^{2}$, Mohsen Pourkemani ${ }^{3}$ \\ ${ }^{1}$ Department of Education, One Territory of Baharestan Education Office, Ministry of Education, Tehran, Iran \\ ${ }^{2}$ Department of Geology, Science and Research Branch, Islamic Azad University, Tehran, Iran \\ ${ }^{3}$ Department of Geology, North Tehran Branch, Islamic Azad University, Tehran, Iran \\ Email: ${ }^{*}$ mehranarian@yahoo.com
}

Received 25 March 2015; accepted 14 April 2015; published 21 April 2015

Copyright (C) 2015 by authors and Scientific Research Publishing Inc.

This work is licensed under the Creative Commons Attribution International License (CC BY).

http://creativecommons.org/licenses/by/4.0/

(c) (i) Open Access

\begin{abstract}
Asmari anticline is a NW-SE fold in the Dezful Embayment sub-basin of Zagros. Fars group (Late Moicene-Quaternary) is cropping out in the cores of anticlines in this area, but Pabdeh and Asmari formations (Oligocene-Early Miocene) have cropped out only in Asmari anticline in the Dezful Embayment. Therefore, it has formed a unique exposure for above formations. In order to this situation, folding mechanism of Asmari anticline has investigated in this research. According to our results, Asmari anticline has two mechanisms: flexural-slip in post-Cretaceous sequences (Khami-Quaternary) and fault-bend folding in pre-Cretaceous sequences. So, there is a hybrid folding mechanism that has introduced for the first time in this paper.
\end{abstract}

Keywords

Asmari Anticline, Mechanism, Hybrid Folding, Zagros, Iran

\section{Introduction}

In this article, we investigated the folding mechanism of a unique structure that has located in the Zagros-East Taurus Hinterland [1]. Dominant structural trends in Zagros Province (Figure 1) are NW-SE in northwestern part and E-W in southeastern part. From tectonics view, it contains the overthrust and simple fold belts of Zagros that formed on the northeastern part of Arabian plate's passive margin. Zagros Mountains have continued to East Taurus Mountains in Turkey and have named Zagros-East Taurus hinterland. The Zagros-East Taurus hinterland has formed an external platform (fold and thrust belt) in north margin of Arabian Craton. Vergence of folding in this hinterland is toward south and southwest [2] [3].

The several landslides, being linear structure in forward limb of the anticline, sulfur springs (Figure 2) and 


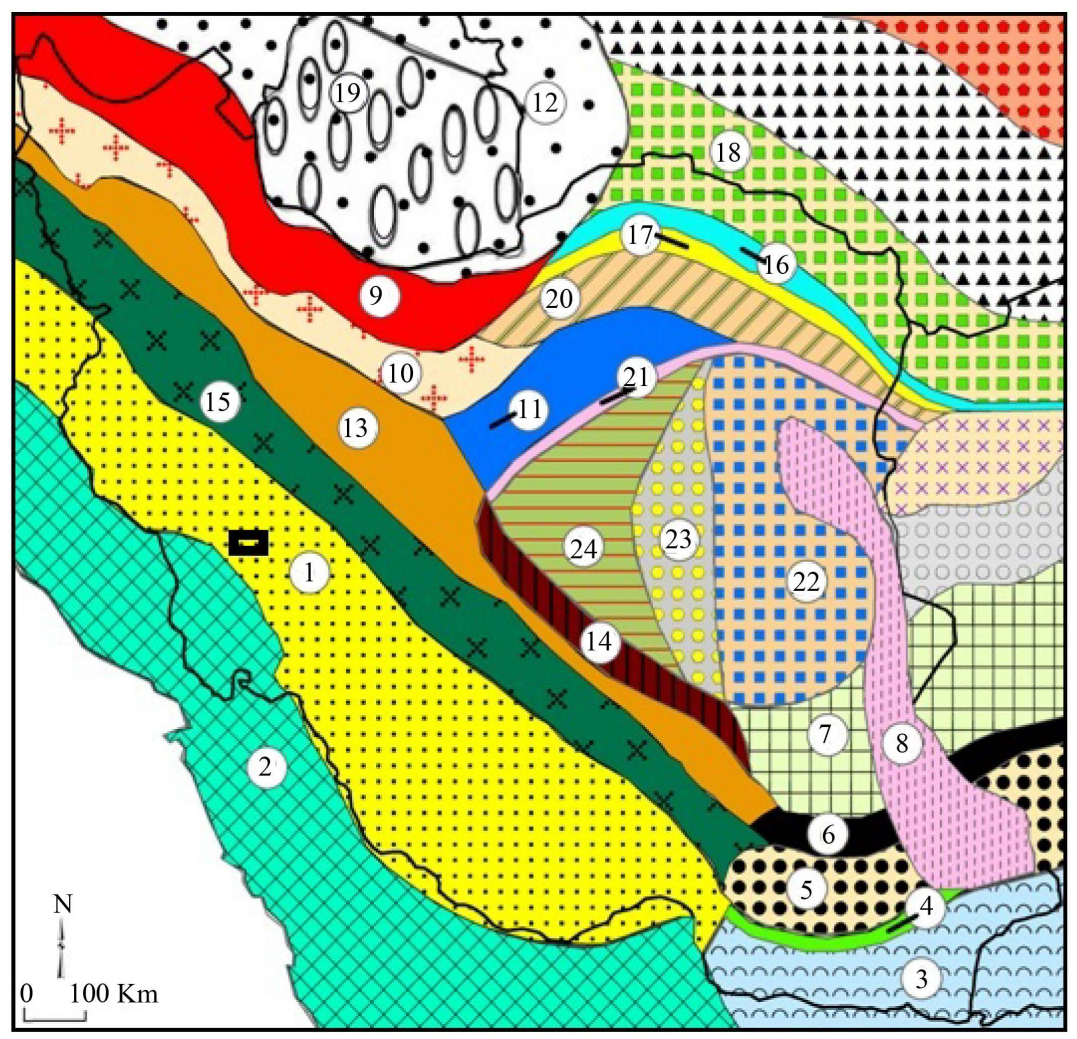

Figure 1. Physiographic-tectonic zoning map of Iran's sedimentary basins Iran modified from [1]. Numbers in this figure are 1: Zagros-East Taurus hinterland; 2: Persian Gulf-Mesopotamian foreland basin; 3: Makran accretionary prism; 4: Bashagard Mountains; 5: Jazmorian-Mashkel fore arc basin; 6: Shahsavaran-Soltan magmatic arc; 7: South Lut-South Helmand back arc basin; 8: East Iran Mountain belt; 9: West-Central Alborz and lesser Caucasus hinterland; 10: Great Kavir-Northen Urmieh lake foreland basin; 11: South Great Kavirfold and thrust belt; 12: South Caspian-Black sea foreland basin; 13: Urmieh-Dokhtar Magmatic arc; 14: Naien-Kerman retro arc foreland basin; 15: Sanandaj-Sirjanoverthrust belts; 16 : East Alborz or Binalod hinterland; 17: Torbat-e am-Neyshabour retro arc foreland basin; 18: KopetDagh hinterland; 19: South Caspian remnant basin; 20: MaiamayTaibad Inverted back arc basin; 21: Khaf-Kavir Plain Magmatic arc; 22: Lut PlainGonabad back arc basin; 23: Tabas hinterland; 24:Yazd-Khour Piggy back basin. The study area is shown in the black rectangle.

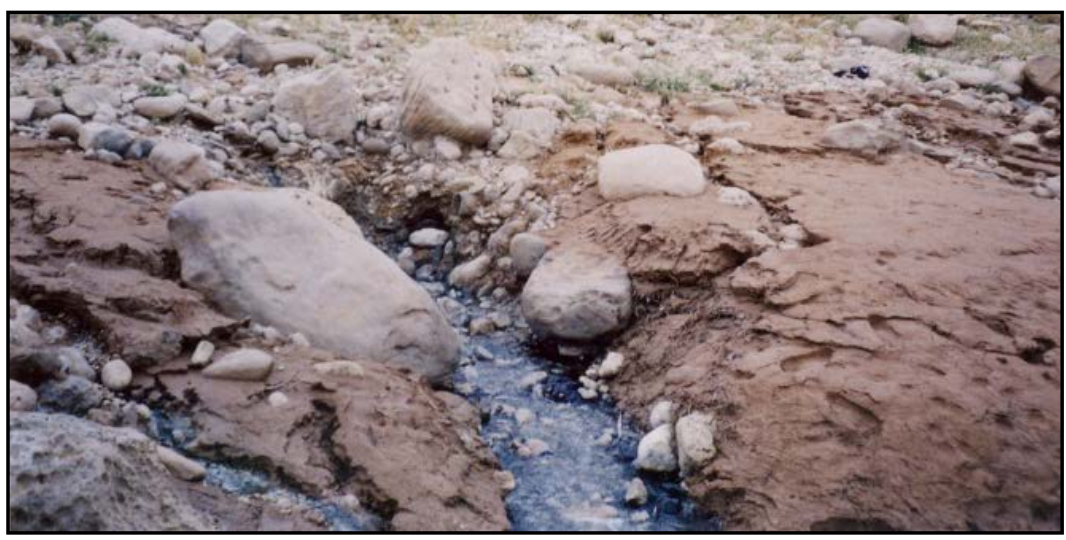

Figure 2. A view from the sulfur springs of Garu in the north-westerly nose of Asmari anticline view toward SE. 
pollution some of them to oil in depth and unusual outcrop of the Asmari and Pabdeh formations have been caused by an especial folding mechanism.

\section{Materials and Methods}

The Dezful Embayment, situated in the western part of the Iranian Zagros fold-thrust belt, hosts most of the hydrocarbon reservoirs of Iran. In the Dezful Embayment, several detachment units have been active during the evolution of Zagros orogenic belt. The lower detachment is within the Hormoz formation (Infra-CambrianLower Paleozoic), and other important detachment units are in the Dashtak formation (Triassic), Kazhdoumi formation (Lower Cretaceous), Pabdeh formation (Paleogene) and Gachsaran formation (Upper Miocene).

The anticlines in the Dezful Embayment are in general asymmetric with a SW vergency. The anticlines are usually to be affected by longitudinal faults and they have been formed some types of fault-related folds.

The Asmari anticline represents a unique Asmari formation outcrop in the Dezful Embayment. Figure 3 shows a generalized stratigraphic overview of the succession in the Dezful Embayment. From Cretaceous through quaternary period, this region is filled by shales of Kazhdoumi formation (Lower Cretaceous), limestones of Ilam and Sarvak formations (Upper Cretaceous), limestones of Ilam and Sarvak formations (Upper Cretaceous), shales and marls of Gurpi and Pabdeh formations (Upper Cretaceous-Oligocene), limesones of Asmari formation (Lower Miocene), evaporates of Gachsaran formation (Upper Miocene) and Plio-quaternary clastics.

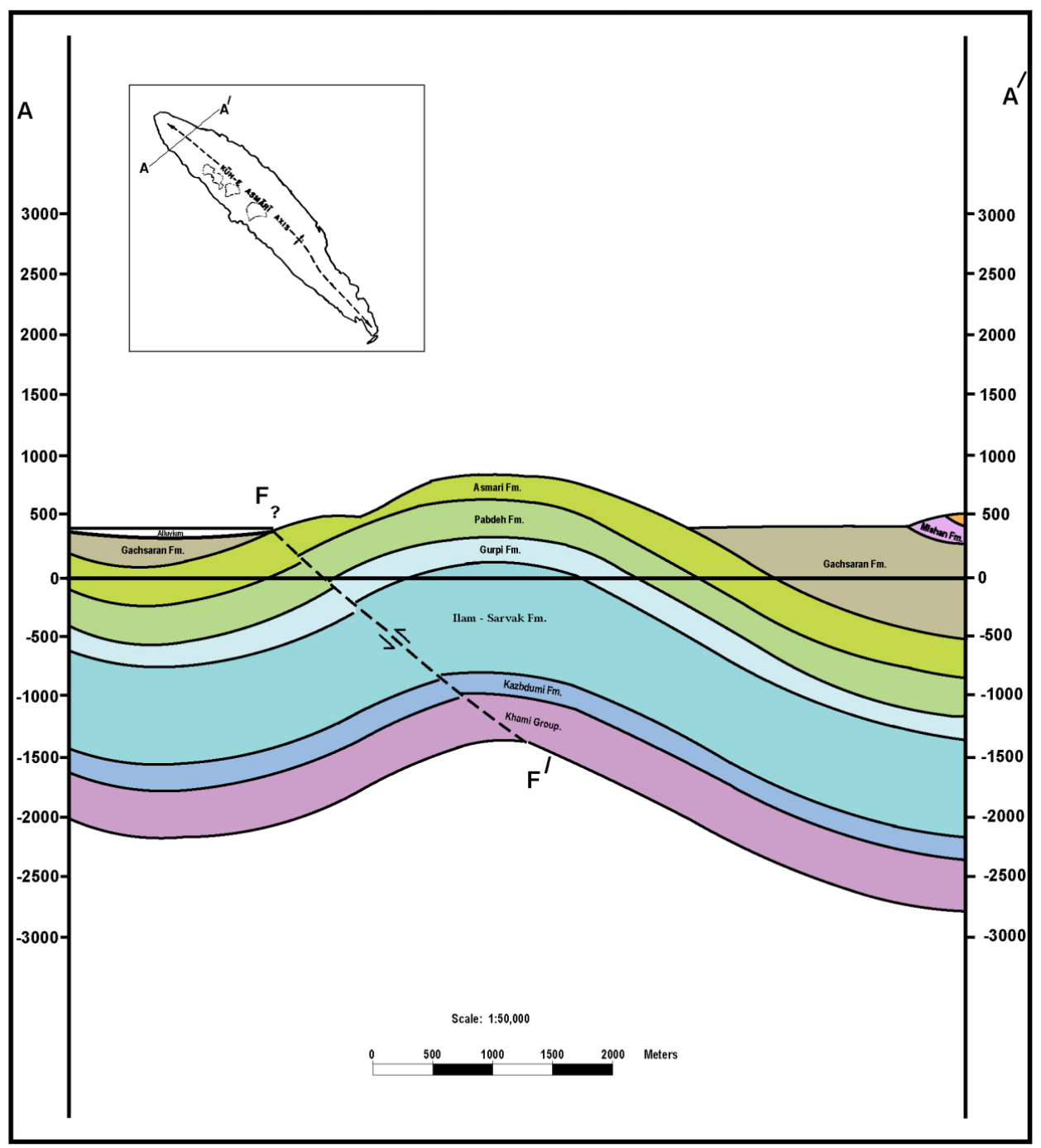

Figure 3. Cross section AA' of the Asmari anticline. 
Asmari anticline is situated in Gulgir village of $22 \mathrm{~km}$ distance SE Masjed-e-Suleyman city. This structure is located between longitudes $49^{\circ} 30^{\prime} \mathrm{E}$ and $49^{\circ} 42^{\prime} \mathrm{E}$ and latitude $31^{\circ} 36^{\prime} \mathrm{N}$ and $31^{\circ} 42^{\prime} \mathrm{N}$ (Figure 1). This anticline with $30 \mathrm{~km}$ length and $10 \mathrm{~km}$ width in axis is a fold decreases toward lateral. Maximal height of fold is in the Asmari formation and fold hinge with $1391 \mathrm{~m}$. The oldest outcrop formation in this area is Pabdeh formation.

From descriptive point of view, Asmari anticline is a whale back, pericline and asymmetric fold. Our geometric analysis have shown post-Cretaceous sequences (Khami-Quaternary) in the Asmari anticline which has formed a sub-cylindrical fold (in middle part), a coniferous with ellipse section fold (in south-easterly and northwesterly) and fore limb slope is more than back limb. Aspect ratio in this anticline is $0.26\left(\mathrm{P}_{\mathrm{E}}=0.26\right)$, so it is a broad fold. Bluntness of fold is $0.56(\mathrm{~b}=0.56)$ and it is a surrounded fold. Folding angle changes from 60 to 75 degree, so it is an open fold. Fourier analysis is calculated in top and base parts of the Asmari formation by using structural cross section and seismic profile. Based on fourier analysis, fold type defines parabolic to sub-elliptical with amplitudes 2 - 3.

True thickness of the Asmari formation (350 meters) and axial surface parallel thickness (450 meters) were measured. Dip isogons mode of the Asmari formation is convergent type (1 class), and dip isogon mode changes from 1A to 1C from anticline core toward limbs [4].

\section{Results and Discussion}

We have prepared four geologic cross sections and a longitudinal section by surveying through the Asmari anticline. The results have been shown by Figures 3-7. The cross sections AA', BB', CC' and DD' have been drawn on the base of the Khami Group and possibly fault (?) has cut its forelimb. This fault can be related to flexural slip mechanism and it may be a main factor of formation of several landslides in forelimb and its linear shape.

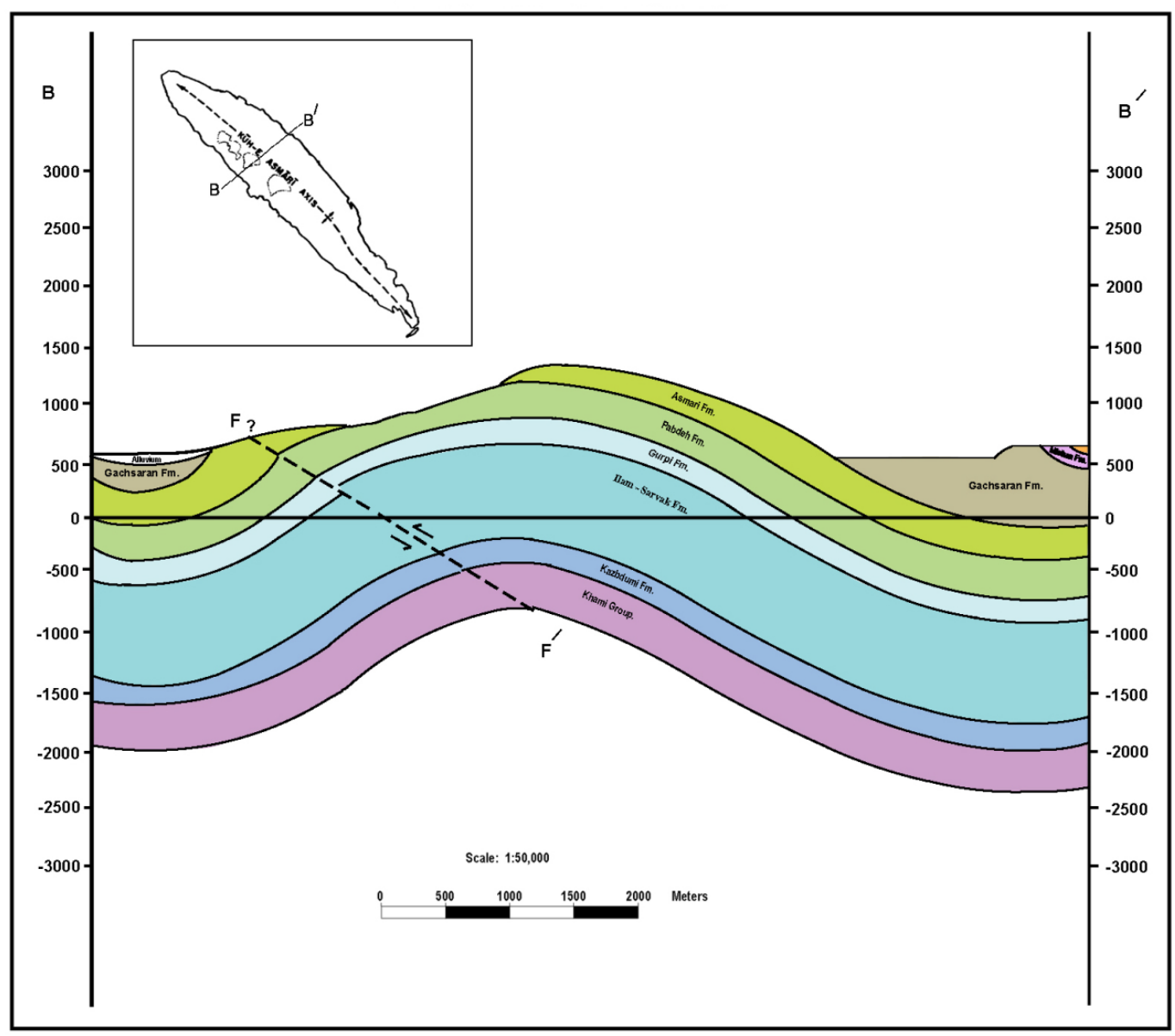

Figure 4. Cross section BB' of the Asmari anticline, modified from [5]. 


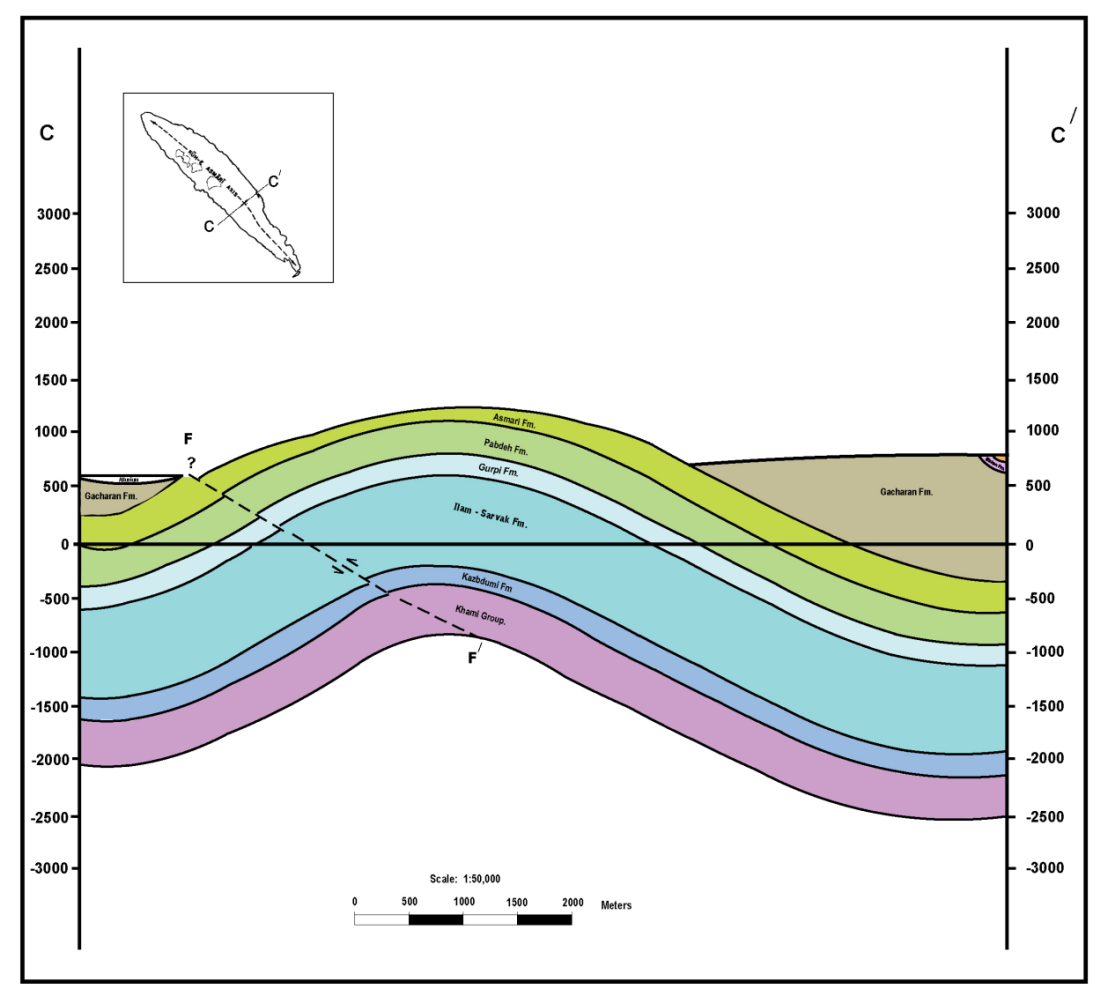

Figure 5. Cross section CC' of the Asmari anticline.

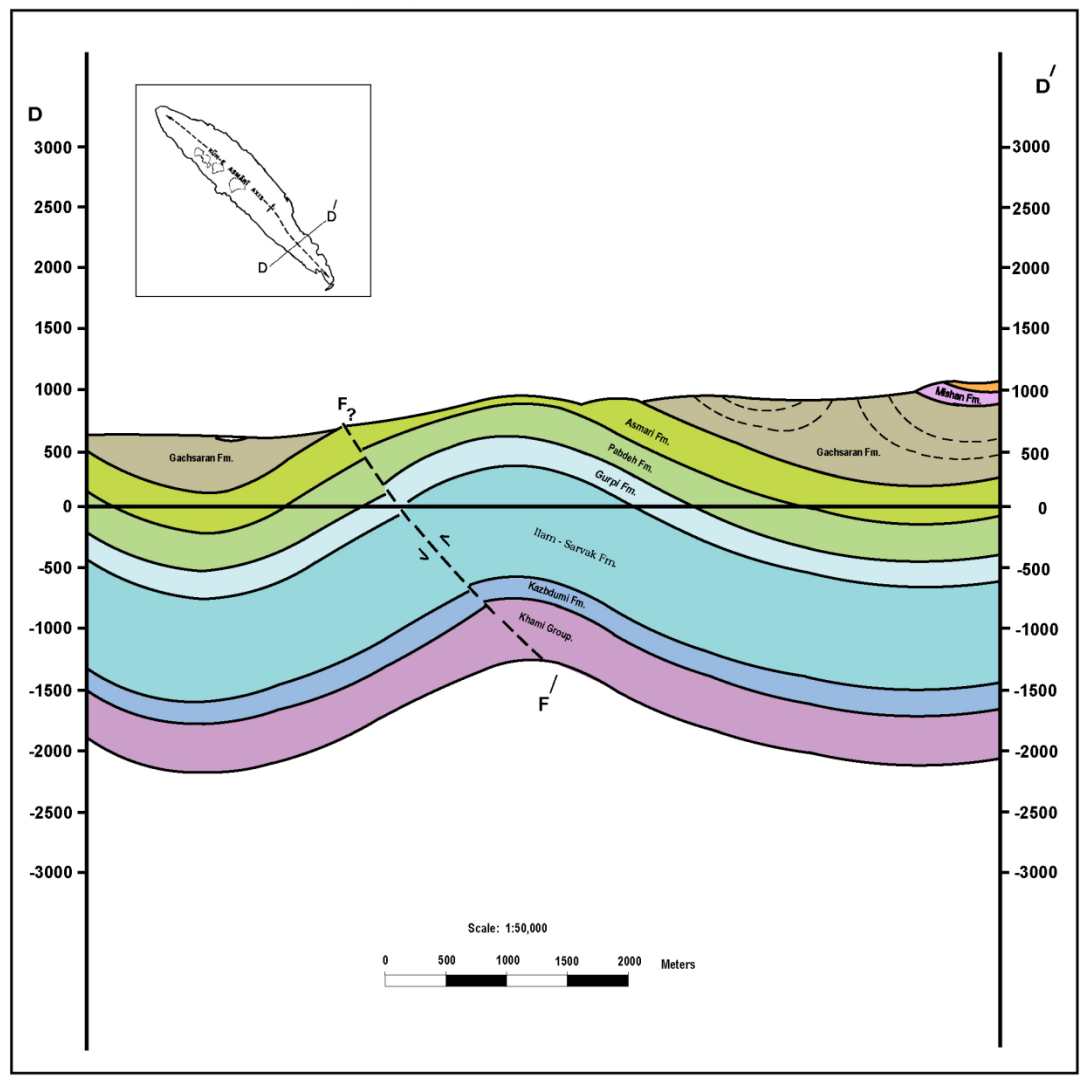

Figure 6. Cross section DD' of the Asmari anticline. 


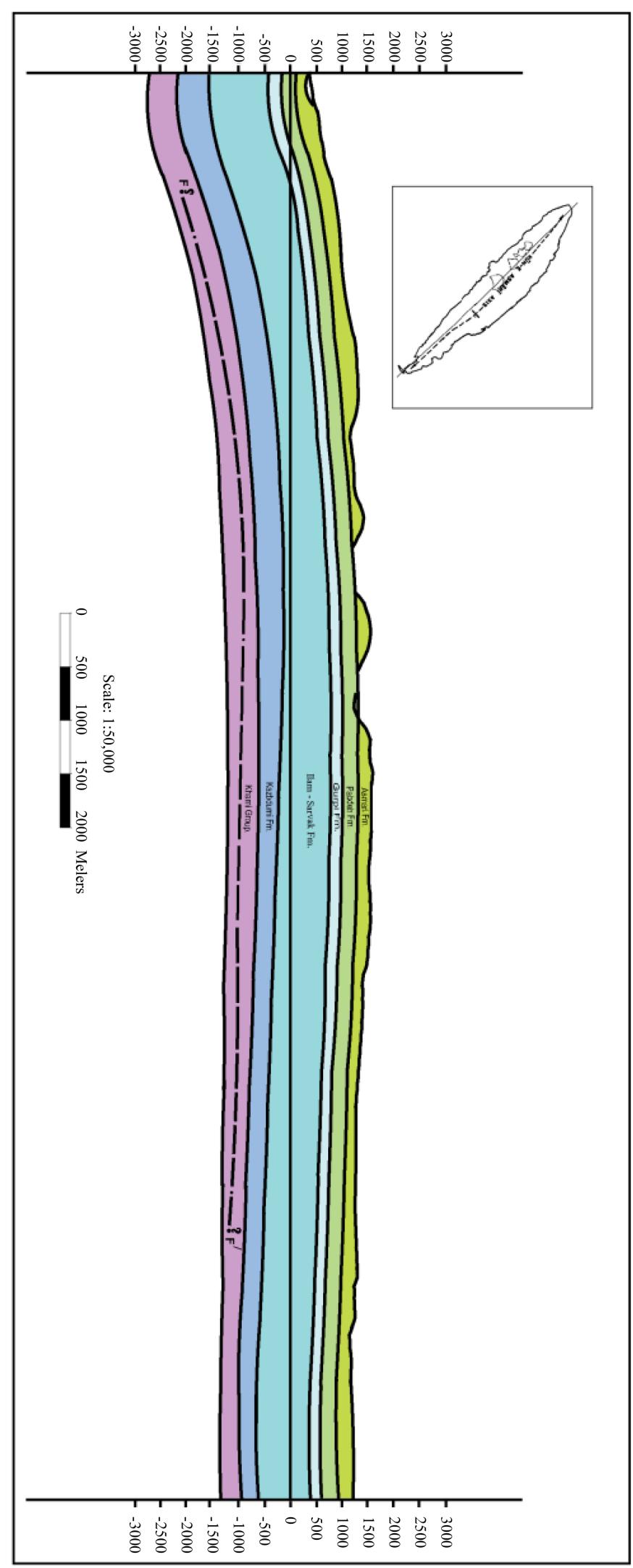

Figure 7. Longitudinal section of the Asmari anticline. 
Based on our previous works [5], pre-Cretaceous sequences in the Asmari anticline shows a fault-bend folding (mode I) in depth (Figure 8) and its forelimb thinning is less than 25 percentages.

Also, from active tectonics point of view, Asmari anticline is an active fold, because Mountain front sinuosity (Smf index) was calculated 1.21 (Figure 9), so it explained that entablature of the Asmari anticline accompanied with active uplifting. Ratio base width of valley altitude (Vf index) was calculated between 4.1 to 31.16. Low amountsof Vf (Figure 10) may be result of performance of active tectonics (Table 1). Based on previous work on the salt diapirism [8]-[17] and neotectonics regime in Iran [18] [19], Zagros in south Iran is the most active zone [20]-[29]. Then, Alborz in north Iran [30]-[59] and Central Iran [60]-[68] have been situated in the next orders.

On the other hand, fracture analysis of the Asmari anticline shows that, in this fold, longitudinal, dextral and sinistral shear fractures (Figure 11) have the most development toward north-westerly nose. Although transverse fractures have developed well toward mid fold.

Fractures survey on the anticline shows these fractures formed before and synchronic with event folding. So we should say fractures on the Asmari formation and older units are forming in sync with anticline formation.

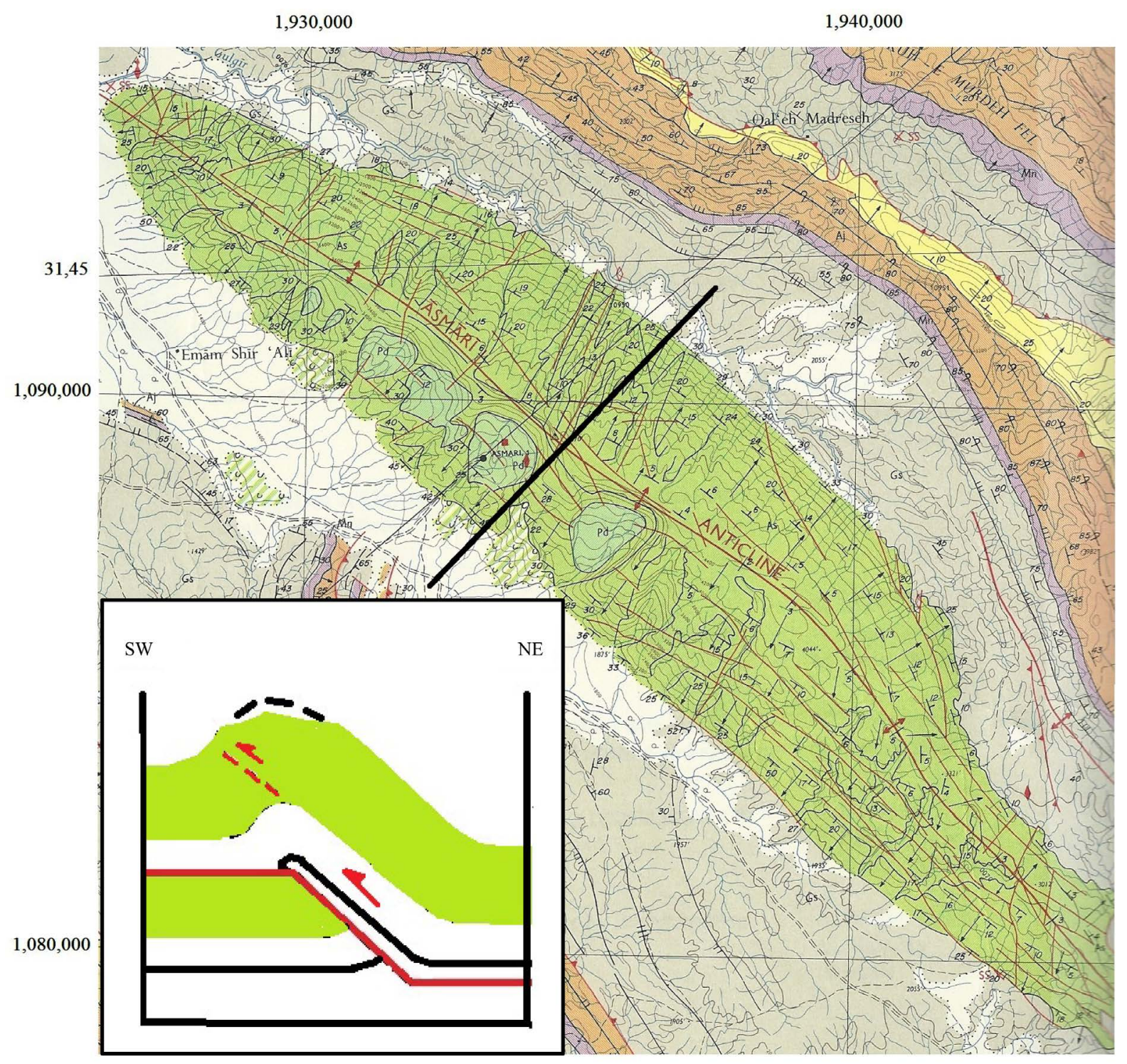

Figure 8. Geologic map of Asmari anticline with a cross section line (black line), modified from [6] and a schematic cross section of Asmari anticline, based on [7]. Post-Cretaceous sequences (Khami-Quaternary) are in green color. 


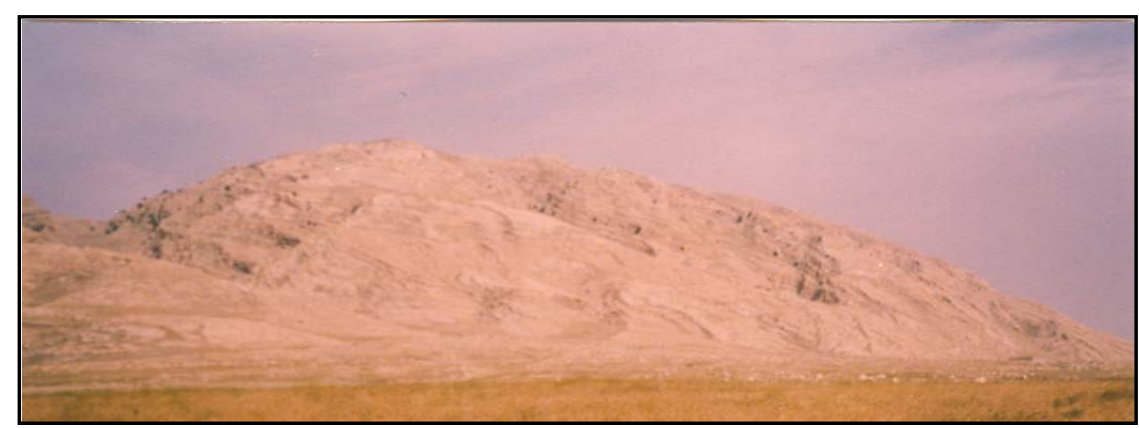

Figure 9. Mountain front of the Asmari anticline, view to the NW.

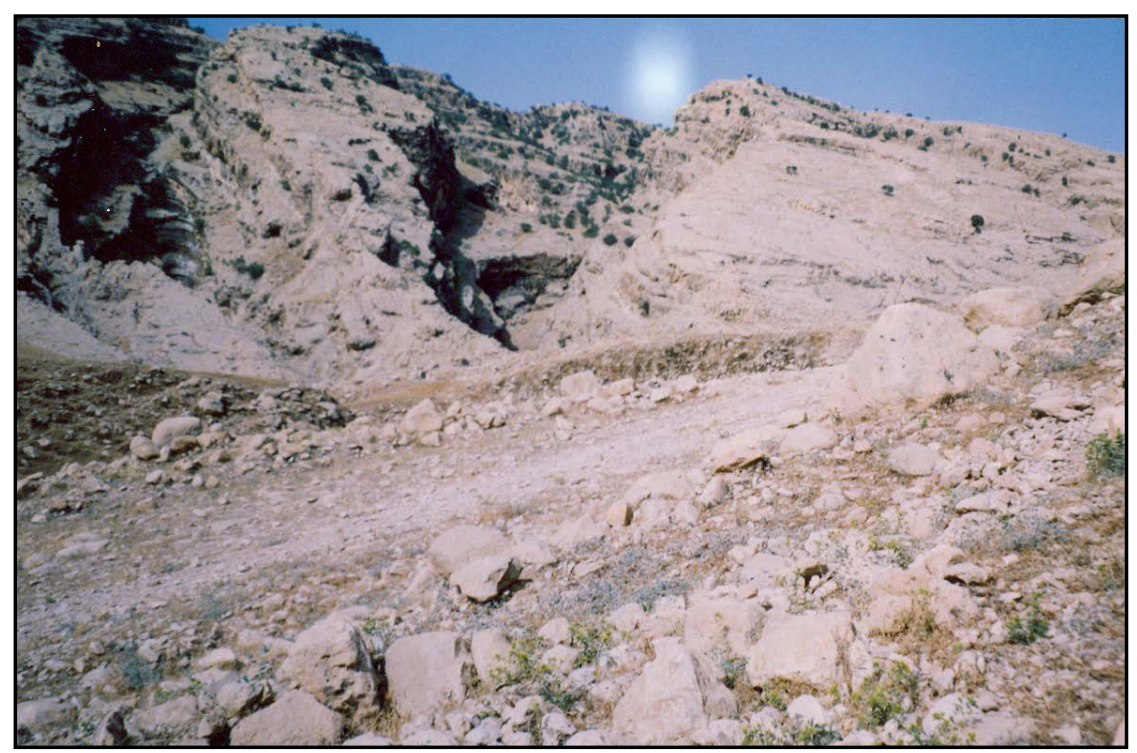

Figure 10. An V shape of valleys on the northeastern limb of the Asmari anticline, view to the SW.

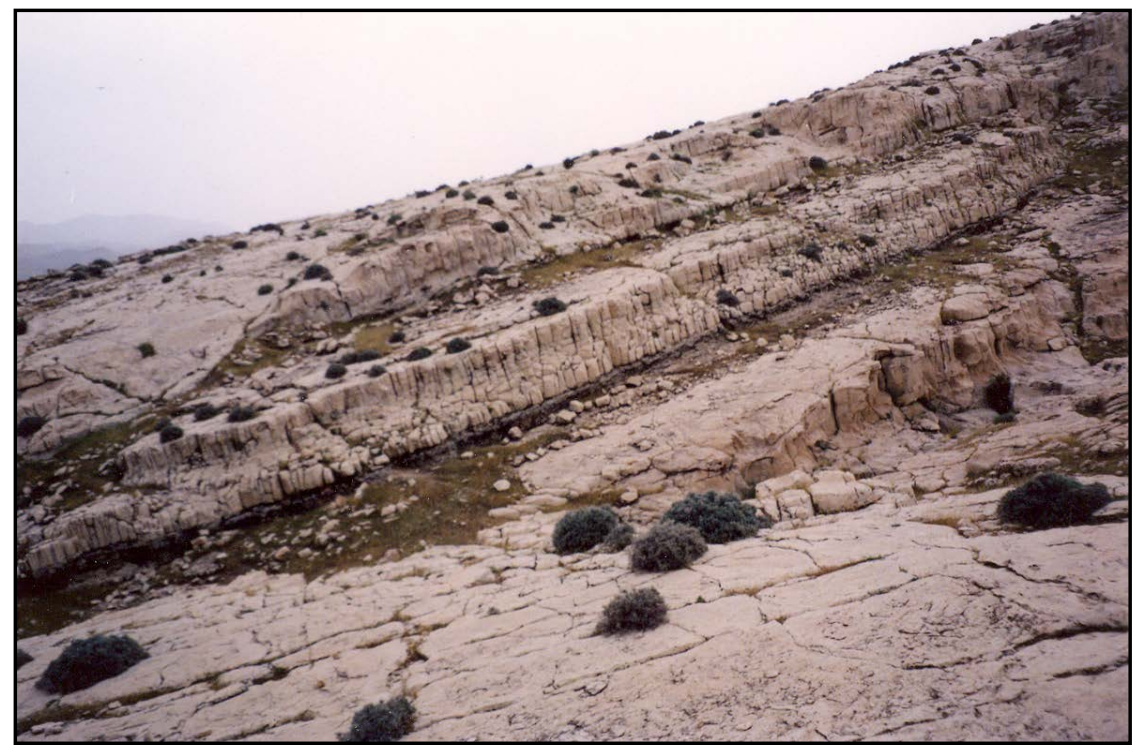

Figure 11. Asmari limestones and their fractures on the northeastern limb of the Asmari anticline, view to the SE. 
Therefore, first migration of the oil fluid was possible where the anticline was uplifted. So, Khami group can be introduced as proper reservoir. There are several springs. Some of these springs originate from the piedmont alluvial reservoirs, and they have water with normal quality, for example, Bidzard spring, Sulfur springs which place in north-westerly nose of the Asmari anticline (Figure 12). Eight other springs have situated along longitudinal fractures in this anticline.

\section{Conclusions}

Hybrid folding mechanism has introduced for the first time for the Asmari anticline. This mechanism has been resulted for combination of flexural-slip folding in post-Cretaceous sequences (Khami-Quaternary) and faultbend folding in pre-Cretaceous sequences. So, there is a hybrid folding mechanism that has introduced for the first time in this paper.

We have investigated mechanism of the Asmari fold by preparation of four cross sections AA', BB', CC' and DD'. Also, geomorphic evidence shows that the Asmari fold is an active fold. Asmari anticline is important because of its oil reservoirs, but clear characteristic phenomenon of Asmari formation is the development of three fracture set (longitudinal, transverse and shear) that caused oil spills from its reservoir. With considera-

Table 1. Values of Vf index.

\begin{tabular}{|c|c|c|c|c|c|}
\hline Station & $\mathrm{E}_{\mathrm{ld}}(\mathrm{m})$ & $\mathrm{E}_{\mathrm{sc}}(\mathrm{m})$ & $\mathrm{E}_{\mathrm{rd}}(\mathrm{m})$ & $\mathrm{V}_{\mathrm{fw}}(\mathrm{m})$ & $\mathrm{V}_{\mathrm{f}}$ \\
\hline 1 & $548 / 64$ & $426 / 72$ & $548 / 64$ & 1000 & $8 / 2020$ \\
\hline 2 & $548 / 64$ & $426 / 72$ & $670 / 56$ & 900 & 5/9055 \\
\hline 3 & $609 / 6$ & $486 / 68$ & $670 / 56$ & 1000 & $6 / 5189$ \\
\hline 4 & $670 / 56$ & $548 / 64$ & $670 / 56$ & 500 & 4/1010 \\
\hline 5 & $670 / 56$ & $548 / 64$ & $670 / 56$ & 600 & 4/9212 \\
\hline 6 & $609 / 6$ & $548 / 64$ & $670 / 56$ & 1100 & 12/0693 \\
\hline 7 & 731/52 & 609/6 & $670 / 56$ & 800 & 8/7489 \\
\hline 8 & $670 / 56$ & 609/6 & $670 / 56$ & 1900 & $31 / 1679$ \\
\hline 9 & 853/44 & $670 / 56$ & 792/48 & 2000 & 13/1232 \\
\hline 10 & 486/68 & $426 / 72$ & $548 / 64$ & 700 & 7/6973 \\
\hline
\end{tabular}

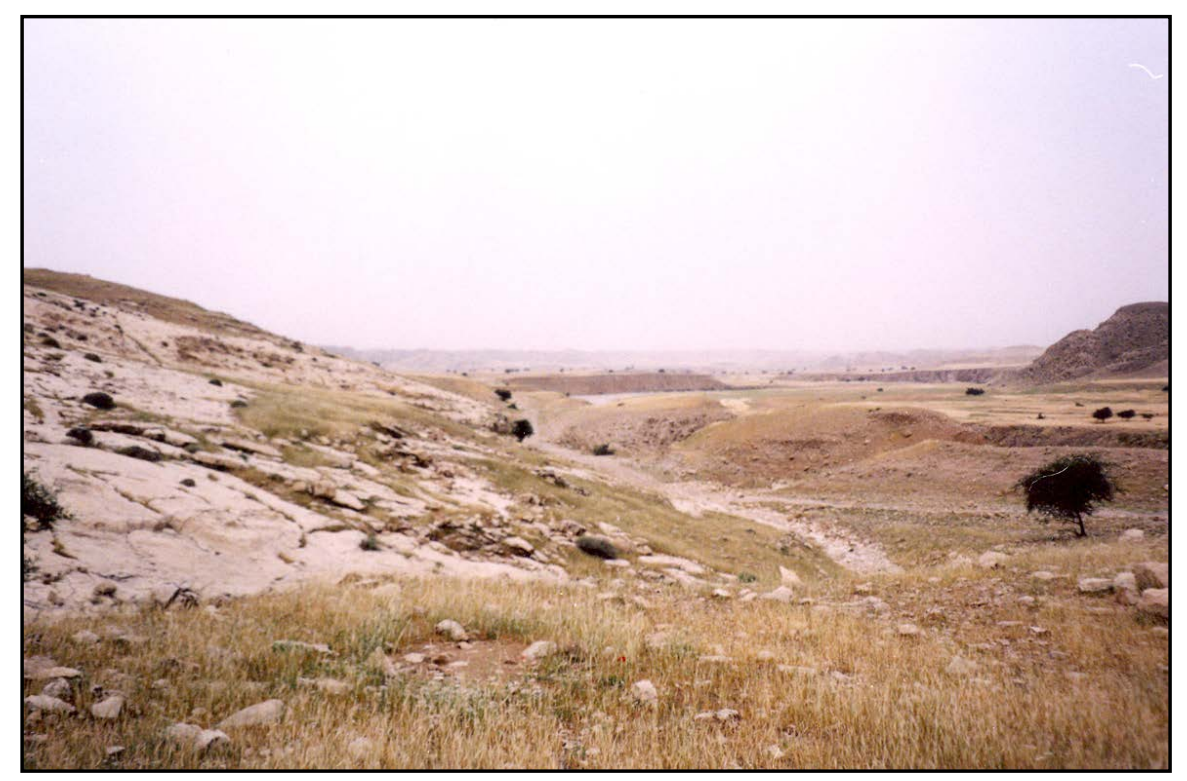

Figure 12. North-westerly nose of the Asmari anticline, view to the SW. 
tion of Asmari fault depth and fractures development before and in sync with anticline formation, we can say when the anticline is uplifted, first migration of the oil fluid is possible on the Asmari formation, so there is impossible oil escape from the Khami group, and it can be surveyed for posterior oil exploration and extraction in this area.

\section{Acknowledgements}

This work has funded by the Department of Geology, Islamic Azad University, Science and Research Branch, Tehran, Iran. Also, Special thanks to vice-president for research in Science and Research Branch, Tehran.

\section{References}

[1] Arian, M. (2013) Physiographic-Tectonic Zoning of Iran’s Sedimentary Basins. Open Journal of Geology, 3, $169-177$. http://dx.doi.org/10.4236/ojg.2013.33020

[2] Qorashi, M. and Arian, M. (2011) Tectonics of Iran. Geologic Survey of Iran, Tehran, 336 p.

[3] Arian, M. (2011) Basement Tectonics and Geology of Iran. Asar Nafis Press, Qum, 300 p.

[4] Khodabakhshnezhad, A., Arian, M. and Pourkermani, M. (2008) The Elements of Fold Style Analysis in the Asmari Anticline (Zagros). Journal of Sciences, 18, 129-138.

[5] Arian, M., Pourkermani, M., Khodabakhshnezhad, A. and Noroozpour, H. (2011) Investigation of Oil Trap in the Asmari Anticline (Zagros, Iran). Indian Journal of Science and Technology, 4, 1696-1699.

[6] Perry, J.T. and Setudehnia, A. (1966) Kuh-e Asmari Geological Compilation Map, 1:100000. National Iranian Oil Company (NIOC), Tehran.

[7] Mapstone, N.B. (1978) Technical Note, No.183. National Iranian Oil Company (NIOC), Tehran.

[8] Arian, M. (2011) A Preface on Salt Diapirism of Iran. Asar Nafis Press, 309 p.

[9] Arian, M. and Noroozpour, H. (2015) The Biggest Salt-Tongue Canopy of Central Iran. Open Journal of Geology, 5, 55-60. http://dx.doi.org/10.4236/ojg.2015.52005

[10] Asadian, F., Pourkermani, M. and Arian, M. (2007) Tectonic Geomorphologyof Salt Structures in the Garmsar-Lasjerd Area. Geographical Research, 39, 75-84.

[11] Pourkermani, M. and Arian, M. (1997) Salt Domes of Central Iran. Journal of Humanities University of Sistan and Baluchestan, 3, 29-41.

[12] Arian, M. (2012) Salt Diapirism and Tectonics. 2nd Edition, Asar Nafis Press, Qum, 319 p.

[13] Arian, M. and Noroozpour, H. (2015) Tectonic Geomorphology of Iran’s Salt Structures. Open Journal of Geology, 5, 61-72. http://dx.doi.org/10.4236/ojg.2015.52006

[14] Asadian, F. and Arian, M. (2009) Identification of Diapiric Provinces of Central Iran through Geological and Geographical Analysis. International Journal of Agriculture Environment \& Biotechnology, 2, 3443-3451.

[15] Arian, M. (2012) Clustering of Diapiric Provinces in the Central Iran Basin. Carbonates and Evaporites, 27, 9-18. http://dx.doi.org/10.1007/s13146-011-0079-9

[16] Pourkermani, M. and Arian, M. (1998) Tectonic Geomorphology of Salt Domes in West of Zanjan Province, Iran. Geographical Research, 47, 44-53.

[17] Arian, M. and Feizi, F. (2010) The Significance of Faulting on the Surficial Spreading of Evaporitic Deposits in the Varamin-Semnan Area. Journal of Earth and Resources, 3, 1-20.

[18] Arian, M. (2011) Middle East Tectonics. 2nd Edition, Asar Nafis Press, Qum, 236 p.

[19] Arian, M. (2010) Applied Seismotectonics. Farazamin Press, Tehran, 304 p.

[20] Arian, M. and Aram, Z. (2014) Relative Tectonic Activity Classification in the Kermanshah Area, Western Iran. Solid Earth, 5, 1277-1291. http://dx.doi.org/10.5194/se-5-1277-2014

[21] Mashal, M., Kermani, M.P., Charchi, A., Almasian, M. and Arian, M. (2013) Pattern of Structural Geology Underground in Eastern of North DEZFOL Embayment. Advances in Environmental Biology, 7, 260-268.

[22] Pazhoohan, M., Arian, M., Ghorashi, M. and Khosrotehrani, K. (2014) A Study of Drainage Pattern Responses to Active Tectonics in Tadvan Region, SW Iran. Geodynamics, 1, 36-41.

[23] Rahimi, N. and Arian, M. (2014) Tectonic Geomorphplogy of Hamedan-Sosangerd Region, West Iran. Advances in Environmental Biology, 8, 119-124.

[24] Arian, M. and Hashemi, A. (2008) Seismotectonic Zoning in the Zagros. Journal of Sciences, 18, 63-76. 
[25] Arian, M., Ahmadnia, A., Qorashi, M. and Pourkermani, M. (2002) Structural Analysis of Mengharak Transcurrent Fault System in Zagros, Iran. Special GEO 2002 Conference Issue Geoarabia, 7, 209-210.

[26] Arian, M., Qorashi, M., Pourkermani, M. and Ahmadnia, A. (2003) Fractal Analysis of Mengharak Transcurrent Fault System in Zagros, in Iran. Abstracts, 4th International Conference on Seismology and Earthquake Engineering, Tehran, 12-14 May 2003, 23.

[27] Baharvand, S., Pourkermani, M., Ajalloian, R., Arian, M. and Nouryazdan, A.R. (2010) Seymareh Landslide and Its Role in Environmental and Geomorphologic Changes of the Pole-Dokhtar Area. Journal of the Earth, 4, 13-24.

[28] Abdideh, M., Qorashi, M., Rangzan, K. and Arian, M. (2011) Assessment of Relative Active Tectonics Using Morphometric Analysis, Case Study of Dez River (Southwestern, Iran). Geosciences Scientific Quarterly Journal, 20, 33-46.

[29] Arian, M., Qorashi, M., Pourkermani, M. and Ahmadnia, A. (2006) The Structural Significance Kareh Bas Transcurrent Fault System in the Zagros Fold and Thrust Belt. Journal of Geosciences, Geological Survey of Iran, 15, 126-133.

[30] Arian, M., Maleki, Z. and Noroozpour, H. (2011) Cenozoic Diastrophism and Deformational Events in the East Central Alborz. Journal of Basic and Applied Scientific Research, 1, 2394-2400.

[31] Feizi, F., Arian, A. and Rahmani, R. (2007) Seismotectonic Zoning in the Eastern Part of the Central Alborz. Journal of Sciences, Islamic Azad University, 17, 151-164.

[32] Khavari, R., Arian, M. and Ghorashi, M. (2009) Neotectonics of the South Central Alborz Drainage Basin, in NW Tehran, N Iran. Journal of Applied Sciences, 9, 4115-4126. http://dx.doi.org/10.3923/jas.2009.4115.4126

[33] Arian, M. and Bagha, N. (2012) Active Tectonics of Tehran Area, Iran. Journal of Basic and Applied Scientific Research, 2, 3805-3819.

[34] Bagha, N., Arian, M., Ghorashi, M., Pourkermani, M., El Hamdouni, R. and Solgi, A. (2014) Evaluation of Relative Tectonic Activity in the Tehran Basin, Central Alborz, Northern Iran. Geomorphology, 213, 66-87. http://dx.doi.org/10.1016/j.geomorph.2013.12.041

[35] Arian, M. and Feizi, F. (2005) Application of Geomorphic Indices to the Assessment of Relative Tectonic Activity Levels in the Alborz-Central Iran Border Zone (from the East of Varamin to the East of Semnan). Journal of Sciences, 15, 378-403.

[36] Arian, M., Bagha, N., Khavari, R. and Noroozpour, H. (2012) Seismic Sources and Neo-Tectonics of Tehran Area (North Iran). Indian Journal of Science and Technology, 5, 2379-2383.

[37] Moghimi, H., Arian, M. and Sorbi, A. (2015) Fault Movement Potential of Marzanabad Area, North Alborz, Iran. Open Journal of Geology, 5, 126-135. http://dx.doi.org/10.4236/ojg.2015.53012

[38] Arian, M. and Pourkermani, M. (2004) Tectonic Elements of South Flank in the East-Central Alborz Mountain. Journal of Sciences, Teacher Training University, 4, 359-368.

[39] Arian, M. and Qorashi, M. (2006) The Movement Potential Evaluation of the Major Quaternary Faults in Alborz-Central Iran Border Zone, from the East of Tehran to the East of Semnan. Journal of Geosciences, Geological Survey of Iran, 15, 184-188.

[40] Poroohan, N., Pourkermani, M. and Arian, M. (2013) An Assessment of Relationship in F-Parameter and Paleostress Fields in Heterogeneous Lithologies: Roudbar Area (Northwest of Iran). Australian Journal of Basic \& Applied Sciences, 7, 933-942.

[41] Poroohan, N., Poukermani, M. and Aryan, M. (2009) An Assessment on Correlations of Seismotectonic Parameters Preceding and Following Roudbar-Manjil Earthquake (Gilan, North of Iran). Australian Journal of Basic \& Applied Sciences, 3, 2643-2652.

[42] Farrokhnia, A.R., Pirasteh, S., Pourkermani, M. and Arian, M. (2011) Geo-Information Technology for Mass Wasting Hazard Zonation: Central-West Alborz Iran. Disaster Advances, 4, 24-33.

[43] Khavari, R., Ghorashi, M. and Arian, M. (2009) Assessment of Relative Active Tectonics, South Central Alborz (North Iran). EGU General Assembly Conference, Abstracts 11, Vienna, 19-24 April 2009, 1137.

[44] Sorbi, A., Arian, M. and Pourkermani, M. (2009) The Movement Potential Evaluation of the Major Quaternary Faults in Tehran Quadrangle. Journal of the Earth, 19, 176-182.

[45] Feizi, F. and Arian, M. (2006) The Classification of Thrust Fronts in the Alborz-Central Iran Border Zone from the East of Varamin to the East of Semnan. Journal of Sciences, 16, 75-87.

[46] Bahiraee, S, Arian, M., Qorashi, M. and Solgi, M. (2015) The Movement Potential Evaluation of the Mosha Fault (the West of Firoozkuh to the Shahrestanak). Geosciences, 24, 123-126.

[47] Arian, M. and Pourkermani, M. (2004) Structural Significance of North Semnan and Attary Faults in Alborz-Central Iran Border Zone. Journal of Sciences, Islamic Azad University, 14, 4551-4569. 
[48] Arian, M. and Pourkermani, M. (2005) Cenozoic Diastrophism and Deformational Events in the Southern Flank of Central-East Alborz. Journal of Earth Sciences, Shahid Beheshti University,Sistan and Baluchestan University, 10, 43-51.

[49] Arian, M., Pourkermani, M., Qorashi, M. and Ghasemi, M.R. (2003) North Semnan Fault System and Its Role on Basin Division. 8th Symposium of Geological Society of Iran, 2, 11-17.

[50] Pourkermani, M. and Arian, M. (2001) Structural Geomorphology of Northeastern Kurdistan, Sistan and Baluchestan University. Journal of Humanities, 7, 37-48.

[51] Mardani, Z., Ghorashi, M. and Arian, M. (2011) Geomorphic Signatures of Active Tectonics in the Talaghan Rud, Shah Rud and Sefidrud Drainage Basins in Central Alborz, Niran. Geosciences, 20, 159-166.

[52] Sorbi, A., Arian, M. and Pourkermani, M. (2011) The Application of Geomorphic Indices to the Assessment of Relative Tectonic Activity Levels in Tehran Quadrangle. Journal of the Earth, 6, 1-9.

[53] Khavari, R., Ghorashi, M., Arian, M. and Khosrotehrani, K. (2010) Geomorphic Signatures of Active Tectonics in the Karaj Drainage Basin in South Central Alborz, Niran. Geosciences Scientific Quarterly Journal, 19, 67-74.

[54] Javadi Mousavi, E. and Arian, M. (2015) Tectonic Geomorphology of Atrak River, NE Iran. Open Journal of Geology, 5, 106-114. http://dx.doi.org/10.4236/ojg.2015.53010

[55] Nouri, R., Jafari, M.R., Arian, M., Feizi, F. and Afzal, P. (2013) Correlation between Cu Mineralization and Major Faults Using Multifractal Modelling in the Tarom Area (NW Iran). Geologica Carpathica, 64, 409-416. http://dx.doi.org/10.2478/geoca-2013-0028

[56] Nouri, R., Jafari, M.R., Arian, M., Feizi, F. and Afzal, P. (2013) Prospection for Copper Mineralization with Contribution of Remote Sensing, Geochemical and Mineralographical Data in Abhar 1:100,000 Sheet, NW Iran. Archives of Mining Sciences, 58, 1071-1084. http://dx.doi.org/10.2478/amsc-2013-0074

[57] Nouri, R., Afzal, P., Arian, M., Jafari, M. and Feizi, F. (2013) Reconnaissance of Copper and Gold Mineralization Using AHP in the Rudbar 1: 100,000 Map Sheet, Northwest Iran. Journal of Mining and Metallurgy A: Mining, 49, 9-19.

[58] Arian, M. and Nouri, R. (2015) Lineament Tectonics and Mineralizatin in Tarom Area, North Iran. Open Journal of Geology, 5, 115-124. http://dx.doi.org/10.4236/ojg.2015.53011

[59] Feizi, F. and Arian, M. (2011) The Role of Structural Controllers in Geneses of Copper Deposits in 1:50000 Map of Saiin Qaleh. Journal of Sciences, 21, 1-10.

[60] Arian, M., Toudeshki, V.H. and Noroozpour, H. (2011) Active Tectonics of Qezel Ozan River Basin, NW Iran. Journal of Applied Environmental and Biological Sciences, 1, 291-295.

[61] Housini Toudeshki, V., Pourkermani, M., Arian, M. and Khosrotehrani, K.H. (2011) Influence of Structures on the Ghezel Ozan River. Geosciences, 21, 55-60.

[62] Housini Toudeshki, V. and Arian, M. (2011) Morphotectonic Analysis in the Ghezel Ozan River Basin, NW Iran. Journal of Geography and Geology, 3, 258-260. http://dx.doi.org/10.5539/jgg.v3n1p258

[63] Alizadeh, H., Arian, M., Lotfi, M., Ghorashi, M. and Ghorbani, M. (2015) Determination of Porphyry Copper Deposit Locations Using Photo Lineament Factor in Northern Parts of the Dehaj-Sardoiyeh Belt. Geosciences, 24, $247-252$.

[64] Arian, M., Pourkermani, M., Sistanipour, A. and Noroozpour, H. (2011) Kinematic Significance of Fold- and FaultRelated Fracture Systems in the Rafsanjan's Northeast Highlands (Central Iran). Journal of Basic and Applied Scientific Research, 1, 3398-3406.

[65] Arian, M., Pourkermani, M., Sistanipour, A. and Noroozpour, H. (2011) Seismicity and Fault Segmentation of Bafq-Baghin Fault System (Central Iran). Journal of Applied Environmental and Biological Sciences, 1, 382-396.

[66] Javadi Mosavi, E., Arian, M., Ghorashi, M. and Nazemi, M. (2012) Measurements of Geomorphic Indices in Tabas Area. Journal of the Earth, 7, 213-225.

[67] Javadi Mosavi, E. and Arian, M. (2015) Active Tectonics of Tabas Area, Central Iran. Open Journal of Geology, 5.

[68] Arian, M. (2010) Earthquake-Fault Hazard Investigations in the Kerman Quadrangle. Journal of Sciences, Islamic Azad University, 19, 176-182. 